\title{
Striatal expression of GDNF and differential vulnerability of midbrain dopaminergic cells
}

\author{
Pedro Barroso-Chinea, ${ }^{1,3}$ Ignacio Cruz-Muros, ${ }^{1}$ María S. Aymerich, ${ }^{4}$ Manuel Rodríguez-Díaz, ${ }^{2}$ \\ Domingo Afonso-Oramas, ${ }^{1}$ José L. Lanciego ${ }^{5}$ and Tomás González-Hernández ${ }^{1}$ \\ ${ }_{1}^{1}$ Departamento de Anatomía, Facultad de Medicina, Universidad de La Laguna, 38207 La Laguna,Tenerife, Spain \\ 2Departamento de Fisiología, Facultad de Medicina, Universidad de La Laguna, Tenerife, Spain \\ ${ }^{3}$ Unidad de Investigación del Hospital Universitario de Canarias, Tenerife, Spain \\ ${ }^{4}$ Departamento de Bioquímica, Clínica Universitaria y Facultad de Medicina, Universidad de Navarra, Centro de Investigación \\ Medica Aplicada, Pamplona, Spain \\ ${ }^{5}$ Departamento de Anatomía, Clínica Universitaria y Facultad de Medicina, Universidad de Navarra, Centro de Investigación \\ Medica Aplicada, Pamplona, Spain
}

Keywords: neuroprotection, Parkinson's disease, rat, substantia nigra, 6-OHDA

\begin{abstract}
Glial cell line-derived neurotrophic factor (GDNF) is a member of the transforming growth factor- $\beta$ superfamily that when exogenously administrated exerts a potent trophic action on dopaminergic (DA) cells. Although we know a lot about its signalling mechanisms and pharmacological effects, physiological actions of GDNF on the adult brain remain unclear. Here, we have used morphological and molecular techniques, and an experimental model of Parkinson's disease in rats, to investigate whether GDNF constitutively expressed in the adult mesostriatal system plays a neuroprotective role on midbrain DA cells. We found that although all midbrain DA cells express both receptor components of GDNF (GFR $\alpha 1$ and Ret), those in the ventral tegmental area (VTA) and rostromedial substantia nigra (SNrm) also contain GDNF but not GDNFmRNA. The levels of GDNFmRNA are significantly higher in the ventral striatum (vSt), the target region of VTA and SNrm cells, than in the dorsal striatum (dSt), the target region of DA cells in the caudoventral substantia nigra (SNcv). After fluoro-gold injection in striatum, VTA and SNrm DA cells show triple labelling for tyrosine hydroxylase, GDNF and fluoro-gold, and after colchicine injection in the lateral ventricle, they become GDNF-immunonegative, suggesting that GDNF in DA somata comes from their striatal target. As DA cells in VTA and SNrm are more resistant than those in SNcv to intracerebroventricular injection of 6-OHDA, as occurs in Parkinson's disease, we can suggest that the fact that they project to vSt, where GDNF expression is significantly higher than in the dSt, is a neuroprotective factor involved in the differential vulnerability of midbrain DA neurons.
\end{abstract}

\section{Introduction}

Glial cell line-derived neurotrophic factor (GDNF) is a distant member of the transforming growth factor- $\beta$ superfamily that together with neurturin, artemin and persephin form the GDNF family of ligands (Airaksinen et al., 1999; Baloh et al., 2000). They exert trophic actions on different cell populations (Henderson et al., 1994; Arenas et al., 1995; Tomac et al., 1995a; Viglietto et al., 2000; Dressler, 2002) by means of a receptor complex composed of a specific high-affinity ligand binding protein, the glycosylphosphatidylinositol-anchored GDNF receptor $\alpha$ component (GFR $\alpha 1$ GFR $\alpha 4$, GFR $\alpha 1$ for GDNF), and a common tyrosine kinase subunit (Ret) that acts as the signalling component (Jing et al., 1996; Saarma, 2000, 2001; Paratcha et al., 2001; Sariola \& Saarma, 2003). Since its characterization and the identification of its neurotrophic effects on mesostriatal dopaminergic (DA) cells (Lin et al., 1993), a great deal of interest has been focused on the potential relevance of GDNF in the treatment of Parkinson's disease (PD). On the basis of studies showing that when exogenously administrated, GDNF supports survival and rescues damaged DA cells

Correspondence: Dr Tomás González Hernández, as above.

E-mail: tgonhern@ull.es

Received 17 November 2004, revised 20 January 2005, accepted 1 February 2005 in culture (Bourque \& Trudeau, 2000; Ma et al., 2000) and in animal models of PD (Gash et al., 1995; Bilang-Bleuel et al., 1997; Grondin \& Gash, 1998; Bjorklund et al., 2000; Kordower et al., 2000; Grondin et al., 2002; Maswood et al., 2002; Grondin et al., 2003) to a higher degree than other neurotrophins (Krieglstein, 2004), GDNF has been proposed as a solid candidate for neuroprotective therapy in PD, and numerous studies have been focused on its successful application to parkinsonian patients (Kordower et al., 1999; Gill et al., 2003; Nutt et al., 2003). In spite of the advances in our knowledge about its signalling mechanisms and pharmacological effects, basic aspects about the physiological role of GDNF remain unclear. For example, we do not know whether constitutively expressed GDNF exerts a neuroprotective role in the adult mesostriatal system. In addition, although different studies indicate that in adulthood, midbrain DA cells express both receptor components of GDNF (Trupp et al., 1996; Golden et al., 1998; Walker et al., 1998; Sarabi et al., 2001), data about GDNF expression vary from author to author, and some of them report that its striatal levels decrease during postnatal development (Stromberg et al., 1993; Springer et al., 1994; Blum \& Weickert, 1995; Choi-Lundberg \& Bohn, 1995), suggesting that in adulthood its neuroprotective effect may be irrelevant. The fact that GDNF does or does not exert a neuroprotective role on adult mesostriatal cells may be 
a key factor in the pathophysiology of PD. Furthermore, its expression pattern may influence the differential vulnerability displayed by different DA cell populations in PD (Fearnley \& Lees, 1991; Gibb \& Lees, 1991; Damier et al., 1999) and against different neurotoxins (Chiueh et al., 1985; Schneider et al., 1987; Herrero et al., 1993; Varastet et al., 1994; Rodriguez et al., 2001b). Bearing in mind these arguments, the aim of the present study was to investigate the expression pattern of GDNF and its receptor components in the adult mesostriatal system and the possible relation between them and neuroprotection in mesostriatal DA cells. We have used immunohistochemistry, in situ hybridization, reverse transcriptase-polymerase chain reaction, injection of retrograde tracers, and an experimental model of PD in rats that reproduces the topographical pattern of cell degeneration observed in PD (Rodriguez et al., 2001a,b).

\section{Materials and methods}

Male Sprague-Dawley rats (Panlab, Barcelona) weighing 300-350 g were housed at $22{ }^{\circ} \mathrm{C}$, two per cage, under normal laboratory conditions in a standard 12-h light : 12-h dark schedule (lights on between 08:00 $\mathrm{h}$ and 20:00 h) with free access to food and water. Experimental protocols were in accordance with the European Communities Council Directive of 24 November 1986 (86/609/EEC) regarding the care and use of animals for experimental procedures. All efforts were made to reduce the number of animals used.

\section{Tissue preparation for morphological study}

The animals were deeply anaesthetized (chloral hydrate, $400 \mathrm{mg} / \mathrm{kg}$, i.p.) and transcardially perfused with $0.9 \%$ saline $(150 \mathrm{~mL})$ and a fixative solution $(400 \mathrm{~mL})$ of $4 \%$ paraformaldehyde in $0.1 \mathrm{M}$ phosphate-buffered saline $\mathrm{pH} 7.4$ (PBS). The brains were removed and stored in the same fixative at $4{ }^{\circ} \mathrm{C}$ for $6 \mathrm{~h}$. Midbrains and forebrains were initially obtained using a brain blocker (Activational System, Warren, MI), immersed overnight at $4{ }^{\circ} \mathrm{C}$ in a cryoprotective solution of $30 \%$ sucrose in the same buffer, and then cut into $30-\mu \mathrm{m}$ coronal sections with a freezing microtome. Sections were collected in 6-8 parallel series and processed by in situ hybridization histochemistry (ISH), immunohistochemistry, double-immunofluorescent labelling or a combination of immunofluorescence and retrograde fluoro-gold transport. Solutions used in the fixation and cryoprotection of material processed by in situ hybridization were treated with $0.1 \%$ diethylpyrocarbonate (DEPC) and autoclaved to inactivate RNases.

\section{Immunohistochemistry and double immunofluorescent labelling}

Midbrain sections were processed by single $\mathrm{TH}$, Ret, GFR $\alpha 1$ and GDNF immunocytochemistry and TH-GDNF double immunofluorescence. For single immunolabelling, sections were immersed for $20 \mathrm{~min}$ in $3 \% \mathrm{H}_{2} \mathrm{O}_{2}$ to inactivate endogenous peroxidase, and incubated for $60 \mathrm{~min}$ at room temperature (RT) in 4\% normal goat serum (NGS, Jackson ImmunoResearch, West Grove, PA), or normal donkey serum (NDS, Jackson ImmunoResearch) in the case of GFR $\alpha 1$, in PBS containing $0.05 \%$ Triton X-100 (Sigma), and overnight in PBS containing $2 \%$ NGS (or $2 \%$ NDS) and one of the primary antibodies, mouse anti-TH monoclonal antibody (1 : 14 000; Sigma, St. Louis, MO), rabbit anti-Ret polyclonal antibody (1:400; Santa Cruz Biotechnology, Santa Cruz, CA), goat anti-GFR $\alpha 1$ polyclonal antibody (1: 400, Santa Cruz Biotechnology), or rabbit anti-GDNF polyclonal antibody (1 : 400; Santa Cruz Biotechnology).
After several rinses, the sections were incubated for $2 \mathrm{~h}$ in either biotinylated goat anti-mouse antiserum (1: 1200, Jackson ImmunoResearch), biotinylated goat anti-rabbit antiserum (1 : 1200, Jackson ImmunoResearch) or biotinylated donkey anti-goat antiserum (1: 1200, Jackson ImmunoResearch), and 1 : 200 NGS (or $1: 200$ NDS) in PBS. Immunoreactions were visible after incubation for $1 \mathrm{~h}$ at RT in ExtrAvidin-peroxidase ( $1: 5000$, Sigma) in PBS, and after $10 \mathrm{~min}$ in $0.005 \% 3^{\prime}-3^{\prime}$-diamiobenzidine tetrahydrochloride (DAB, Sigma) and $0.001 \% \mathrm{H}_{2} \mathrm{O}_{2}$ in cacodylate buffer $0.05 \mathrm{M} \mathrm{pH}$ 7.6. After several rinses in PBS, the slides were dehydrated, cleared in xylene, and coverslipped with DPX (BDH Chemicals, Poole, England).

Double-immunofluorescent labelling was studied by using epifluorescence and confocal microscopy. In both cases, the sections were first incubated for $1 \mathrm{~h}$ in $4 \%$ NGS and $0.05 \%$ Triton X-100 in PBS, and then overnight in the same solution containing mouse anti-TH monoclonal antibody $(1: 8000)$ and rabbit anti-GDNF polyclonal antibody $(1: 200)$. Epifluorescent labelling was visible after incubation for $3 \mathrm{~h}$ in Fluorescein Isothiocyanate-conjugated goat anti-mouse IgG (1 : 150; Jackson ImmunoResearch) and Lissamine Rhodamineconjugated goat anti-rabbit IgG (1: 150; Jackson ImmunoResearch) in PBS containing $1: 200$ NGS. Confocal images were visible after incubation for $2 \mathrm{~h}$ in Alexa Fluor ${ }^{\circledR}$ 546-conjugated goat anti-mouse IgG (1 : 100; Molecula Probes, Eugene, OR) and Alexa Fluor ${ }^{\circledR} 488$ conjugated donkey anti-rabbit IgG (1:100; Molecula Probes) in PBS containing 1:200 NGS and 1:200 NDS. After several rinses, sections for epifluorescence were air dried, coverslipped with Vectashield (Vector, Burlingame, CA), and examined under a fluoromicroscope (Leica Microsystems; Wetzlar, Germany) using appropriate filters. Sections for confocal microscopy were air dried, immersed in toluene, coverslipped with Entellan ${ }^{\circledR}$ (Merk; Darmstadt, Germany) and examined under a laser scanning confocal microscope (LSM 510 META, Zeiss; Overkochen, Germany) equipped with an argon laser with excitation wavelengths of 458, 477, 488 and $514 \mathrm{~nm}$ and with one helium-neon laser with an excitation wavelength of $543 \mathrm{~nm}$. To ensure the appropriate visualization of labelled elements and to prevent false positive results, the emission from the argon laser at $488 \mathrm{~nm}$ was filtered through a band pass filter of $505-530 \mathrm{~nm}$, this emission was colour-coded in green. The emission from the excitation with the helium laser at $543 \mathrm{~nm}$ was filtered through a band pass filter of 560-615 nm, and colour-coded in red. For each immunocytochemistry and immunofluorescence, control experiments were performed by removing the primary antibody, resulting in negative staining.

\section{In situ hybridization histochemistry}

The antisense and the control sense rat digoxigenin-labelled GDNF riboprobes used in this study were produced by in vitro transcription of GDNF cDNA obtained by PCR. Total rat RNA was isolated from rat striatum by using Trizol reagent (Life Technologies, Gaithersburg, $\mathrm{MD})$. The cDNA was obtained by incubating $2 \mu \mathrm{g}$ of total RNA, $1 \mathrm{~mm}$ dNTP mix, $3 \mathrm{~mm}$ DTT, 5 pM hexamers, $40 \mathrm{U}$ RNase inhibitor (Promega, Madison, WI) and $200 \mathrm{U}$ M-MLV reverse transcriptase (Gibco, Carlsbad, CA) in a final volume of $30 \mu \mathrm{L}$ during $1 \mathrm{~h}$ at $37^{\circ} \mathrm{C}$. The full-length GDNF cDNA (644 bp) was amplified by PCR under the following conditions: $3 \mu \mathrm{L}$ of total cDNA, $0.3 \mathrm{mM}$ dNTP, $1 \mathrm{~mm}$ $\mathrm{MgSO}_{4}, 0.2 \mu \mathrm{M}$ primers and $2.5 \mathrm{U}$ of Platinum/Pfx/DNA polymerase (Invitrogen, Carlsbad, CA) in a final volume of $50 \mu \mathrm{L}$. The primer sequences were: sense 5'-CTAAGATGAAGTTATGGGATG-3' and antisense 5'-AGGGTCAGATACATCCACACC-3'. The PCR product was analysed by electrophoresis, the single band excised, purified and cloned. The GDNF was transcribed with the appropriate RNA polymerases to synthesize either the sense or antisense probes 
using commercial reagents (Roche Diagnostics, Mannheim, Germany). The $50 \mu \mathrm{L}$ transcription mixture included $1 \mu \mathrm{g}$ template cDNA, $1 \mathrm{~mm}$ of each ATP, CTP and GTP, $0.7 \mathrm{mM}$ UTP and $0.3 \mathrm{~mm}$ DIG-UTP, 10 mM DTT, 50 U RNase Inhibitor, and $1 \mathrm{U}$ of either T3 or T7 RNA polymerase. After $2 \mathrm{~h}$ at $37{ }^{\circ} \mathrm{C}$, the template cDNA was digested with $2 \mathrm{U}$ of RNase-free DNAse for $30 \mathrm{~min}$ at $37^{\circ} \mathrm{C}$. Then, the riboprobes were precipitated by the addition of $100 \mu \mathrm{L}$ of $4 \mathrm{M}$ ammonium acetate and $500 \mu \mathrm{L}$ ethanol and centrifuged at $4{ }^{\circ} \mathrm{C}$ for $30 \mathrm{~min}$. The quality of the synthesis was monitored by Northern blot.

Midbrain and forebrain floating sections were incubated twice with $0.1 \%$ active DEPC/PBS containing $2 \%(\mathrm{w} / \mathrm{v})$ proteinase $\mathrm{K}$ for $15 \mathrm{~min}$. After pre-equilibration with $5 \times \mathrm{SSC}(0.75 \mathrm{M} \mathrm{NaCl}, 0.075 \mathrm{M}$ NaCitrate), the sections were prehybridized at $58{ }^{\circ} \mathrm{C}$ for $1 \mathrm{~h}$ in hybridization solution ( $50 \%$ formamide, $5 \times \mathrm{SSC}, 40 \mu \mathrm{g} / \mathrm{mL}$ denatured salmon DNA). The probes were denatured for $5 \mathrm{~min}$ at $80{ }^{\circ} \mathrm{C}$, added to the hybridization mix at $400 \mathrm{ng} / \mathrm{mL}$, and the sections were hybridized in this solution at $58{ }^{\circ} \mathrm{C}$ for $16 \mathrm{~h}$. Posthybridization washes included $2 \times \mathrm{SSC}$ at RT for $30 \mathrm{~min}, 2 \times \mathrm{SSC}$ at $65^{\circ} \mathrm{C}$ for $1 \mathrm{~h}$ and $0.1 \times \mathrm{SSC}$ at $65{ }^{\circ} \mathrm{C}$ for $1 \mathrm{~h}$. Then, the slides were equilibrated for $5 \mathrm{~min}$ in $\mathrm{TN}$ buffer (100 mM TrisHCl, $150 \mathrm{mM} \mathrm{NaCl}, \mathrm{pH} 7.5)$, and incubated for $2 \mathrm{~h}$ at RT with alkaline-phosphatase conjugated antiDIG monoclonal antibody (1 : 5000 final dilution in TN with $0.5 \%$ blocking reagent, Roche Diagnostics). After two 15 min washes in TN buffer, the slides were equilibrated for $5 \mathrm{~min}$ in TNM buffer $(100 \mathrm{mM}$ TrisHCl, $100 \mathrm{mM} \mathrm{NaCl}, 50 \mathrm{mM} \mathrm{MgCl}_{2}, \mathrm{pH}$ 9.5) and incubated in substrate solution (NBT and BCIP in TNM buffer, Roche Diagnostics) for $8 \mathrm{~h}$. Staining was stopped in TE $(10 \mathrm{~mm}$ TrisHCl, $1 \mathrm{~mm}$ EDTA, $\mathrm{pH}$ 8.0), and the slides were dehydrated and mounted. Control experiments were performed for each ISH by skipping the antisense riboprobe or using their control sense probe, which resulted in an absence of staining.

\section{Fluoro-gold injection}

A total of seven rats received a single injection of Fluoro-gold (FG, Florochrome, Denver, CO; $0.1-0.3 \mu \mathrm{L}, 4 \% \mathrm{w} / \mathrm{v}$ in $0.9 \%$ saline) in the left striatum using a glass micropipette attached to a Hamilton microsyringe. In three rats the injection was localized in the dorsal striatum and in the other four in the ventral striatum. After a survival time of 4-5 days, they were deeply anaesthetized (chloral hydrate, $400 \mathrm{mg} / \mathrm{kg}$, i.p.) and transcardially perfused. The brains were removed and processed by TH-GDNF double-immunofluorescence as described above.

\section{6-Hydroxydopamine (6-OHDA) lesion}

Rats were anaesthetized with ketamine $(25-40 \mathrm{mg} / \mathrm{kg}$ i.p.; Rhône Mérieux; Lyon, France) and xylazine $(3-6 \mathrm{mg} / \mathrm{kg}$ i.p.; Bayer, Leverkusen, Germany), and injected in the third ventricle [midline, $2 \mathrm{~mm}$ posterior to bregma and $8 \mathrm{~mm}$ below the dura, according to Paxinos \& Watson (1998)] with vehicle $(0.9 \%$ saline solution with $0.3 \mu \mathrm{g} / \mu \mathrm{L}$ ascorbic acid, sham group, $n=5$ ) or a single dose of (300 or $500 \mu \mathrm{g}$ ) of 6-OHDA (6-hydroxydopamine hydrochloride, Sigma, in $7.5 \mu \mathrm{L}$ of vehicle per injection; $1 \mu \mathrm{L} /$ minute, 6-OHDA groups, $n=6$ in each of them). In order to prevent the degeneration of noradrenergic cells, the rats were treated with nortriptyline 20 min before injection (30 mg/kg in saline, i.p.; nortriptyline hydrochloride, Sigma). Special care was taken in anaesthesia because in our experience, nortriptyline significantly increases the effect of ketamine, affecting cardiopulmonary functions during surgery. Bearing in mind that the bilateral degeneration of DA cells can cause adipsia and aphagia (Ungerstedt, 1971; Longo,
1973; Zigmond \& Stricker, 1973), the intake of water and food was monitored during the weeks following the 6-OHDA injection, until ingestion and weight were similar to that of the control rats. These animals were killed after a survival period of 4 weeks and processed by TH immunohistochemistry following the protocol described above.

\section{Division of the midbrain DA formation for the morphological study}

Although the midbrain DA formation is composed of three main regions: A8, A9 and A10 (Dahlström \& Fuxe, 1964), our study was mainly focused on A9 and A10. Bearing in mind cytoarchitectural and neurochemical criteria (McRitchie et al., 1996; Gonzalez-Hernandez \& Rodriguez, 2000) and the topographical pattern of degeneration observed in PD (Bernheimer et al., 1973; Hirsch et al., 1988; Damier et al., 1999) and different models of PD (Chiueh et al., 1985; Schneider et al., 1987; Herrero et al., 1993; Varastet et al., 1994; Rodriguez et al., 2001b), A9 was divided into two subregions: (i) the caudo-ventro-lateral region of the $\mathrm{SN}(\mathrm{SNcv})$, that includes A9 DA cells in the ventrolateral region of the SN pars compacta (SNC) and the SN pars reticulata (SNR), and (ii) the rostro-dorso-medial region of the SNC (SNrm); and A10 into (i) the ventral tegmental area and parabrachial pigmented nucleus (VTA/PBP), containing medium and large cells in the paramedial ventral midbrain and above SNC, respectively, and (ii) the rostral and caudal linear nuclei and interfascicular nucleus ( $\mathrm{Li} / \mathrm{IF})$, formed by small cells in and close to the midbrain midline. The morphological study was performed separately in these four subdivisions.

\section{Tissue preparation for reverse transcriptase-polymerase chain reaction ( $R T-P C R)$ analysis}

The ventral midbrain and striatum were dissected from six freshly obtained rat brains and RNA was extracted using the acid phenol method. The midbrain region containing A9 and A10 [between $3.00 \mathrm{~mm}$ and $4.00 \mathrm{~mm}$ rostral to the interaural axis; Paxinos \& Watson (1998] was obtained by using a brain blocker and placed on a cold plate. With the aid of a stereomicroscopy and using a scalpel for ophthalmic surgery, the dorsal midbrain was removed and two regions were dissected in the ventral part; a caudoventrolateral one containing the two lateral thirds of the SNC and SNR (SNcv), and a rostrodorsomedial one containing the medial third of the SNC (SNrm) and A10. In the striatum, bearing in mind the topographical distribution of mesostriatal DA projections in the rat (Fallon \& Moore, 1978; Gerfen et al., 1987; Jimenez-Castellanos \& Graybiel, 1987; Joel \& Weiner, 2000), we distinguished two different regions, the dorsal striatum, which includes the two dorsal thirds of the dorsal striatum and which is the main target of $\mathrm{SNcv}$, and the ventral striatum, that includes the ventral third of the dorsal striatum and the accumbens nucleus and which is the main target of SNrm and A10.

\section{$R T-P C R$ analysis}

Two micrograms of total RNA were reverse transcribed after heat denaturation $\left(5 \mathrm{~min}, 65^{\circ} \mathrm{C}\right.$ ) and annealing of oligo-dT primers. AMVreverse transcriptase (Roche Diagnostics) was used for cDNA synthesis, under the conditions recommended by the manufacturer, in a final volume of $20 \mu \mathrm{L}$. As a control for the amount of cDNA synthesized in different samples, $1 \mu \mathrm{L}$ of a $1: 5$ dilution of the cDNA was used as a template for PCR amplification of $\beta$-actin, a constitutively expressed gene. One microlitre of undiluted cDNA 
was also used to amplify GDNF (NM 019139) in tubes of $25 \mu \mathrm{L}$ final reaction volume. Amplification reactions included $0.2 \mathrm{mM}$ dNTPs, $0.5 \mu \mathrm{M}$ each primer, 0.5 U Taq DNA polymerase (Promega) and $1 \times$ PCR buffer $\mathrm{pH} 9.0$, with final $1.5 \mathrm{mM} \mathrm{MgCl}_{2}$. Thirty cycles of the following temperature profiles were performed in a MJR thermocycler: $94{ }^{\circ} \mathrm{C} \quad(1 \mathrm{~min}) \quad 65{ }^{\circ} \mathrm{C} \quad(1 \mathrm{~min}) \quad 72{ }^{\circ} \mathrm{C} \quad(1 \mathrm{~min})$ for $\beta$-actin amplification, and $94{ }^{\circ} \mathrm{C}(1 \mathrm{~min}) 58{ }^{\circ} \mathrm{C}(1 \mathrm{~min}) 72{ }^{\circ} \mathrm{C}(1 \mathrm{~min})$ for GDNF amplification. Fifteen microlitres of the PCR product were separated in $5 \%$ acrylamide gels, stained with $0.5 \mu \mathrm{g} / \mathrm{mL}$ ethidium bromide and digital images were captured under UV light. The sequences of the primers used, and the expected molecular size of the amplification products are: rGDNF-F $5^{\prime}$-GACTCTAAGATGAA GTTATGG-3', rGDNF-R 5'-TTTGTCGTACATTGTCTCGG-3'; rActin-F 5'-AATGAGCGGTTCCGATGCCC-3', 482 bp; rActin-R 5'-GGACAGTGAGGCCAGGATAGA-3', 297 bp.

\section{Quantitative analysis}

In order to get a quantitative estimate of the relationship between GDNF expression and neuroprotection, we used cell count and densitometric analysis in the midbrain and striatum. The parameters analysed were: (i) number and localization of $\mathrm{TH}$ cells showing immunoreactivity for GDNF; (ii) number and localization of cells containing GDNFmRNA; (iii) number and localization of TH cells 4 weeks after 6-OHDA injection, and (iv) densitometric analysis of GDNFmRNA in RT-PCR product. All studies were performed on five rats per group. Six sections, $180 \mu \mathrm{m}$ apart from each other in the rostrocaudal axis, were randomly selected in each rat for cell counting. In each section, midbrain DA regions were divided into fields of $300 \mu \mathrm{m} \times 250 \mu \mathrm{m}$, at a magnification of $\times 200$. Only cell profiles with a sectioned nucleus were analysed. The total number of TH profiles was compared to that of Cresyl violet-stained cells in order to prevent a possible underestimation of the number of TH positive cells due to down-regulation in TH activity in 6-OHDA treated rats.

In RT-PCR, bands were quantified by using a Bio-Rad scanner with densitometry software. Briefly, a rectangle of uniform size and shape was placed over each band and the density per area $\left(\mathrm{mm}^{2}\right)$ was calculated. The background was subtracted from each measurement.

\section{Statistical analyses}

Mathematical analyses were performed using the one-way ANOVA followed by the Tukey honest test for multiple posthoc comparisons. Analysis was performed using the Statistica program (Statsoft; Tulsa, USA). A level of $P<0.05$ was considered as critical for assigning statistical significance.

\section{Results}

\section{GDNF and its receptor components in the midbrain dopaminergic formation}

In the rat midbrain we found Ret immunostaining (Fig. 1A) in DA cells in A8 (retrorubral field), A9 (substantia nigra, SN) and the different subnuclei of A10; ventral tegmental area (VTA), pigmented parabrabraquial nucleus (PBP), rostral and caudal linear nuclei (Li) and the interfascicular nucleus (IF). GFR $\alpha 1$ immunostaining was found in the same cell groups as Ret and in neurons throughout the substantia nigra pars reticulata (Fig. 1B). These data agree with previous studies reporting that midbrain DA cells express both components of the GDNF receptor (Trupp et al., 1996; Golden et al., 1998; Sarabi et al., 2001) and that nigral GABAergic neurons express
GFR $\alpha 1$ (Sarabi et al., 2001). In addition, immunohistochemistry for GDNF revealed that a subpopulation of cells mainly localized in A10 (Fig. 1C) and the rostro-dorso-medial region of SNC (SNrm; Fig. 1D-F) contain GDNF. Double labelling for GDNF and TH, using both epifluorescence (Fig. 2) and confocal images (Fig. 3), confirmed that they are dopaminergic neurons. In epifluorescence, quantification of the number of TH cells that contain GDNF in different subregions of the midbrain dopaminergic formation revealed a decreasing gradient of double-labelled cells from dorsomedial to ventrolateral regions (Table 1; Figs 2 and 4A). In the medial region of A10 (IF and IL), $73 \%$ of TH cells contain GDNF; in the lateral region of A10 (VTA and $\mathrm{PBP}$ ) this percentage was $54 \%$; in the rostromedial third of the SNC (SNrm), 38\%, and in the two lateral third of SNC and SNR $(\mathrm{SNcv})$, the percentage was not higher than $8 \%$. In confocal microscopy, we found that in SNcv numerous DA neurons display GDNF immunoreactivity (Fig. 3D-F), although their labelling intensity, compared to those in dorsomedial regions, was very low (compare Fig. 3B and E). This suggests that many A9 and A10 DA cells contain GDNF, although in SNcv, GDNF levels are too low to be detected by epifluorescence.

\section{Synthesis of midbrain GDNF}

To elucidate whether midbrain GDNF is synthesized by midbrain cells or by their target in striatum, we performed in situ hybridization and RT-PCR analysis for GDNF in both the midbrain and striatum (Fig. 5). Bearing in mind that DA cells containing GDNF are mostly localized in A10 and SNrm, and as mentioned in the Materials and methods, that mesostriatal projections follow a well established topographical pattern (Fallon \& Moore, 1978; Gerfen et al., 1987; JimenezCastellanos \& Graybiel, 1987; Joel \& Weiner, 2000), for RT-PCR analysis, both the midbrain dopaminergic formation and striatum were divided into two regions. In the midbrain we distinguished a dorsomedial region containing A10 and SNrm, and another one containing SNcv. In the striatum, we distinguished a dorsal region (dSt) containing the two dorsal thirds of the dorsal striatum, which is the main target of $\mathrm{SNcv}$, and a ventral region (vSt) containing the ventral third of the dorsal striatum and the accumbens nucleus, which are the main target of A10 and SNrm. ISH (Fig. 5A-E) and RT-PCR (Fig. 5F) revealed GDNFmRNA in the striatum but not in the midbrain. In addition, both techniques showed topographical differences in the levels of GDNF expression in striatum. In ISH, GDNFmRNA positive cells were preferentially localized in the vSt, with a density of $9.3 \pm 2.0$ stained cells per $\mathrm{mm}^{2}$ in each section (Fig. 5C-E), while in the dSt the density of stained cells was $3.1 \pm 1.2$ (Fig. 5B and E). Consistent with these findings, the levels of GDNFmRNA levels in RT-PCR analysis were significantly higher in vSt than in dSt $(P<0.01$; Fig. 5F).

To support the hypothesis that GDNF contained in midbrain DA cells comes from their striatal targets, we found that after injection of colchicine (an inhibitor of protein transport) in the lateral ventricle, $\mathrm{TH}$ neurons in A10 and SNrm became immunonegative for GDNF (Fig. 4B and C). In addition, after fluoro-gold (FG) injection in the striatum, numerous cells in A10 and SNrm displayed TH-GDNF-FG triple labelling (Fig. 4D-F).

\section{GDNF expression pattern and neuroprotection}

The fact that GDNF was preferentially synthesized in the vSt and retrogradely transported by midbrain DA neurons projecting to this region suggested that this phenomenon may constitute a resistance 


\section{Ret}

\section{GFRalpha1}

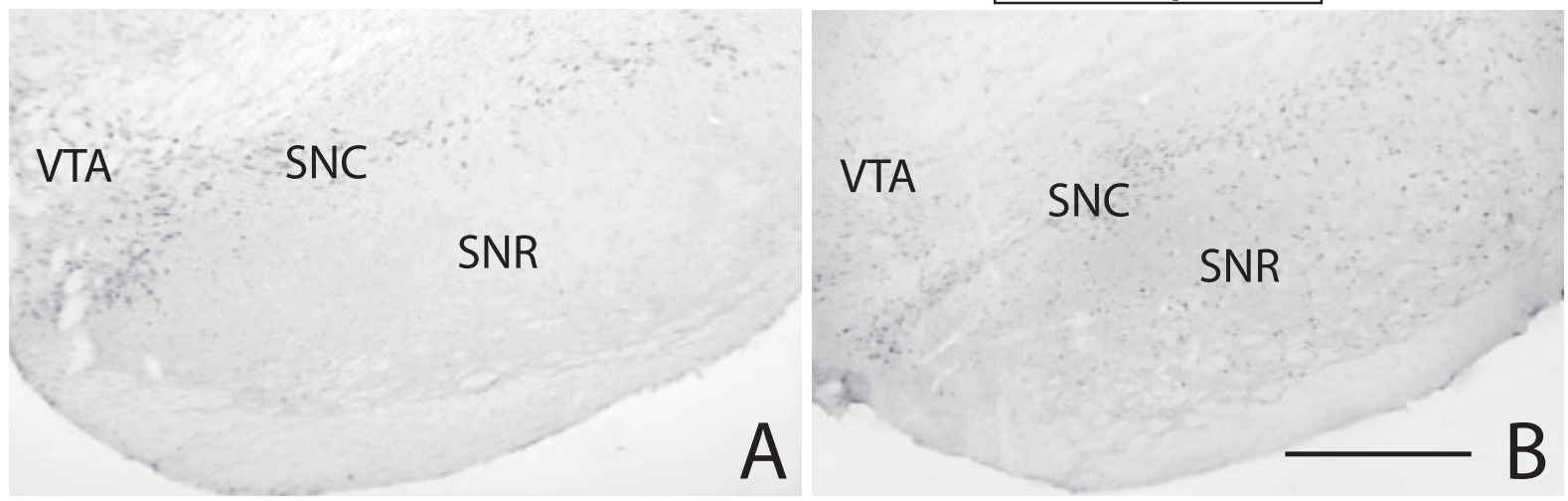

\section{GDNF}
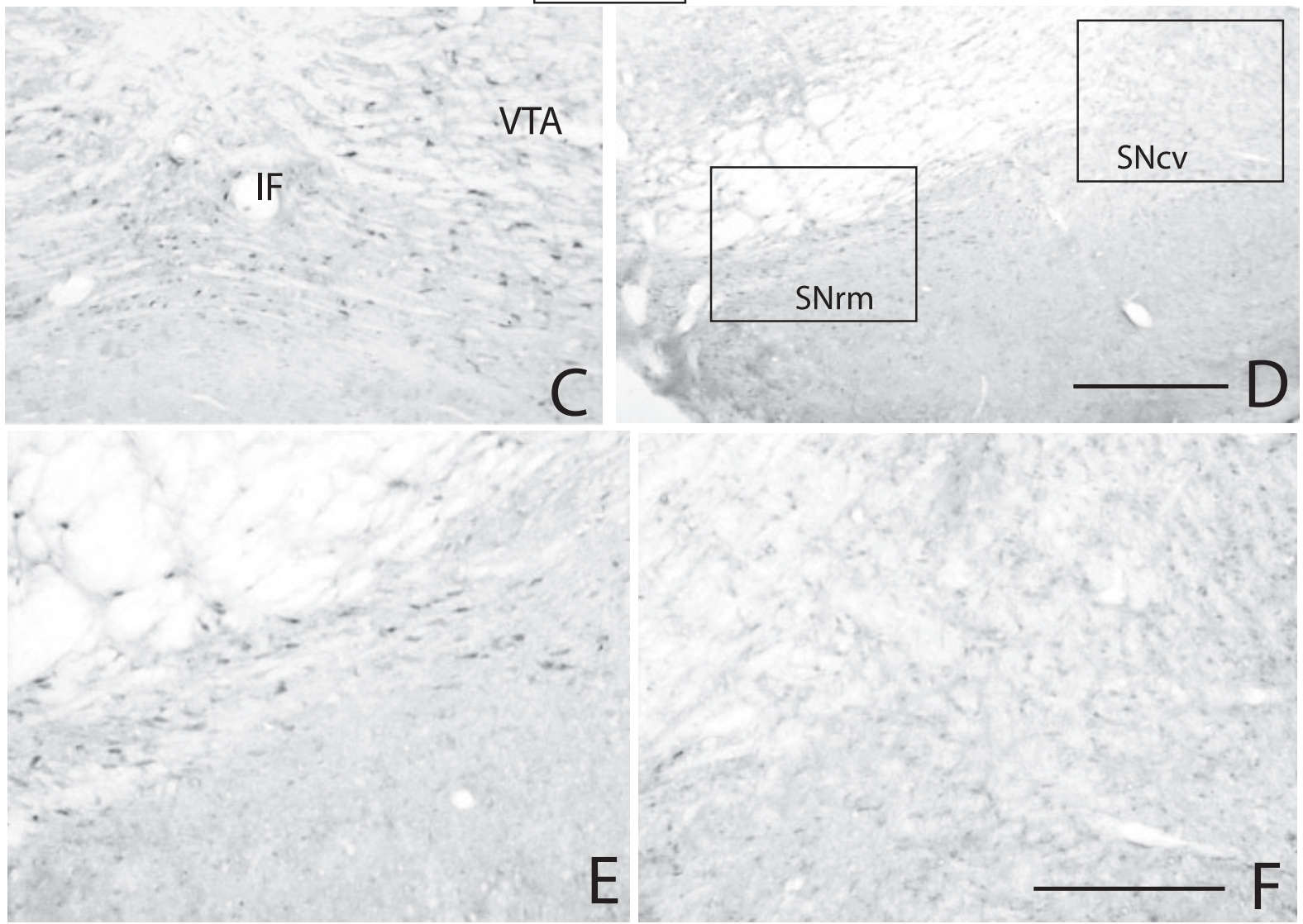

FIG. 1. Immunohistochemistry for Ret (A), GFR $\alpha 1$ (B) and GDNF (C-F) in frontal sections of the midbrain. Note that Ret-immunoreactive neurons are preferentially localized in the VTA and SNC, while GFR $\alpha 1$-immunoreactive neurons localize in the VTA, SNC and also in the SNR. C-F show that many neurons are also immunoreactive for GDNF in the IF, VTA and SNrm, but not in the SNcv. (E) Boxed area on the left in D; (F) boxed area on the right in D. IF, interfascicular nucleus; SNC, substantia nigra pars compacta; SNcv, caudo-ventro-lateral region of the substantia nigra; SNR, substantia nigra pars reticulata; SNrm, rostro-dorso-medial region of the substantia nigra. Scale bar, $1 \mathrm{~mm}(\mathrm{~B}$, for A and B); $600 \mu \mathrm{m}(\mathrm{D}) ; 200 \mu \mathrm{m}(\mathrm{F}$, for C, E and F).

factor against degeneration for this midbrain DA cell population. To explore this hypothesis we studied the topographical distribution and the number of midbrain DA cells containing GDNF after intracerebroventricular injection (i.c.v.) of 6-OHDA, an experimental model of midbrain DA cell degeneration in the rat that reproduces the main behavioural and anatomical landmarks of PD (Rodriguez et al., 2001a,b). On the basis of our experience in the use of this experimental model, we used two different doses $(300 \mu \mathrm{g}$ and
$500 \mu \mathrm{g}$ ) of $6-$ OHDA. The lesion degree was evaluated by counting the number of surviving DA neurons ( $\mathrm{TH}$ immunoreactive cells) 4 weeks after injection. The effect of i.c.v. injection of 6-OHDA was bilateral, symmetrical and dose-dependent, and the lesion degree varied from one region to another (Fig. $4 \mathrm{G}$ and $\mathrm{H}$; Table 1). A low magnification view showed that the distribution pattern of surviving neurons matches that of DA cells containing GDNF, lying mostly in A10 and SNrm (compare Fig. 4A and H). Cell count (Table 1) 

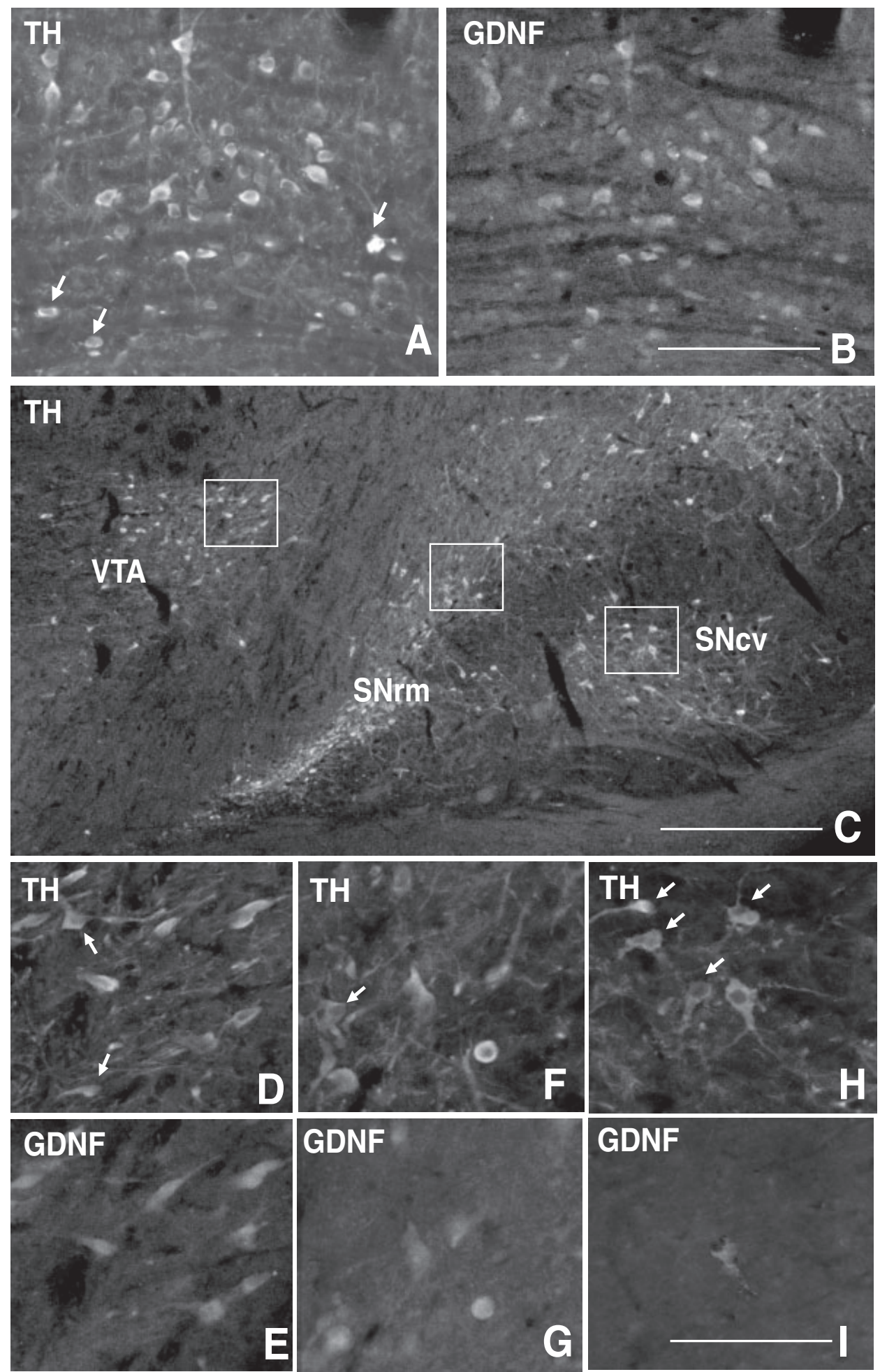

FIG. 2. Double immunofluorescence for TH (A, C, D, F and H) and GDNF (B, E, G and I) in midbrain sections. (A and B), interfascicular nucleus; (D, F and H), boxed areas on the left, middle and right side, respectively, in $\mathrm{C}$. We can see that many neurons in the interfascilular nucleus show double labelling, and that as we move towards ventrolateral regions the number of TH cells immunoreactive for GDNF decreases ( $\mathrm{H}$ and $\mathrm{I})$. Arrows in A, D, F and $\mathrm{H}$ indicate TH cells that are not immunoreactive for GDNF. SNcv, caudo-ventro-lateral region of substantia nigra; SNrm, rostro-dorso-medial region of the substantia nigra; VTA, ventral tegmental area. Scale bar, $100 \mu \mathrm{m}$ (B, for A and B); $250 \mu \mathrm{m}$ (C); in $50 \mu \mathrm{m}$ (I, D-I).

revealed that after i.c.v. injection of $300 \mu \mathrm{g}$ of $6-\mathrm{OHDA}$, the number of $\mathrm{TH}$ positive cells in the $\mathrm{SNcv}$ decreases to $22 \%$ with respect to the sham-injected group, in the SNrm to $44 \%$, in VTA/PBP to $62 \%$, and in $\mathrm{Li} / \mathrm{IF}$ to $68 \%$. In $500 \mu \mathrm{g}$ 6-OHDA injected rats, the effect was more intense than in the $300 \mu \mathrm{g}$ 6-OHDA injected ones. In all regions, with the exception of $\mathrm{Li} / \mathrm{IF}$ where only a slight reduction in the cell number was observed (64\%), the number of surviving neurons decreased significantly; to $6 \%$ in SNcv, $29 \%$ in SNrm, and $45 \%$ in 

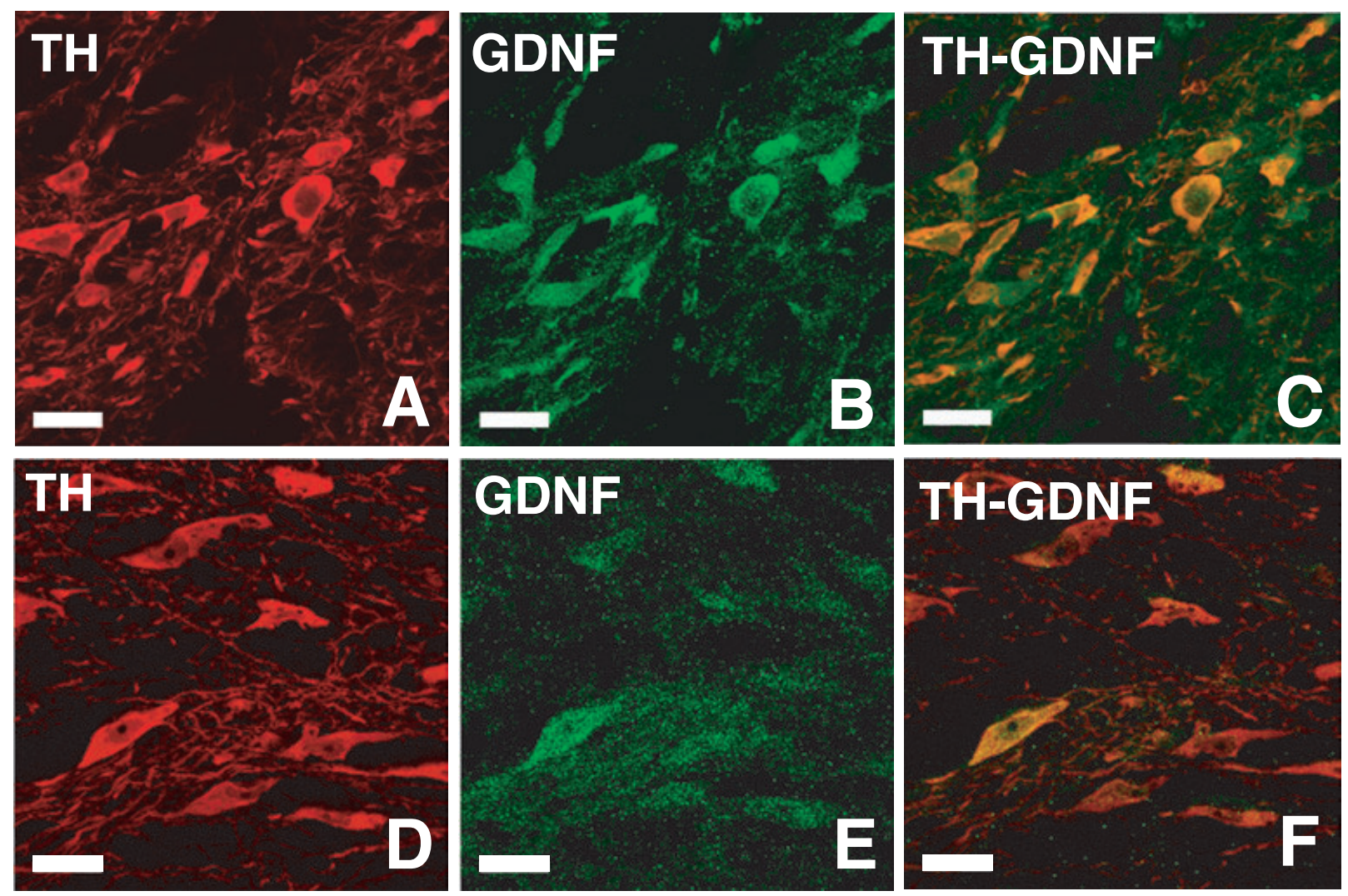

FIG. 3. Confocal images showing GDNF immunoreactivity in TH cells in the ventral tegmental area (VTA; A-C) and the caudoventral region of the substantia nigra (SNcv; D-F). Note that VTA DA cells show a robust GDNF labelling while in most SNcv DA cells GDNF labelling is minimal or absent. Scale bar, $20 \mu \mathrm{m}$.

TABLE 1. Quantification of TH cells in different subregions of the midbrain dopaminergic formation

\begin{tabular}{|c|c|c|c|c|c|}
\hline & $n$ & $\mathrm{Li} / \mathrm{IF}$ & VTA/PBP & SNrm & $\mathrm{SNcV}$ \\
\hline TH-cells showing GDNF-immunoreactivity in control rats (\%) & 5 & $72.7 \pm 2.5$ & $54.4 \pm 4.6$ & $38.3 \pm 3.9$ & $8.1 \pm 2.1$ \\
\hline TH-cells surviving after i.c.v. injection of $300 \mu \mathrm{g}$ 6-OHDA (\%) ${ }^{\dagger}$ & 5 & $68.1 \pm 7.2^{* * *}$ & $62.0 \pm 4.5^{* * *}$ & $43.8 \pm 5.1^{* * *}$ & $22.2 \pm 5.9 * * *$ \\
\hline TH-GDNF cells after i.c.v. injection of $300 \mu \mathrm{g}$ 6-OHDA (\%) & 5 & $80.8 \pm 3.1 * *$ & $72.1 \pm 3.2 * * *$ & $73.0 \pm 5.8^{* * *}$ & $71.3 \pm 3.3 * * *$ \\
\hline TH-cells surviving after i.c.v. injection of $500 \mu \mathrm{g} 6$-OHDA $(\%)^{\dagger}$ & 5 & $63.7 \pm 6.4$ & $44.9 \pm 8.3 * * * *$ & $29.1 \pm 4.2^{* * * *}$ & $6.2 \pm 1.4 * * * *$ \\
\hline TH-GDNF cells after i.c.v. injection of $500 \mu \mathrm{g} 6$-OHDA (\%) & 5 & $77.6 \pm 3.9 *$ & $68.6 \pm 1.5^{* * *}$ & $69.7 \pm 8.0 * * *$ & $72.8 \pm 4.9 * * *$ \\
\hline
\end{tabular}

${ }^{\dagger}$ Compared with sham-injected rats $(n=5)$; ${ }^{\dagger}$ with respect to the total number of TH cells; $* P<0.05$ v.s. sham; $* * P<0.01$ v.s. sham; $* * * P<0.001$ v.s. sham; $* * * * P<0.01$ v.s. $300 \mu \mathrm{g}$ 6-OHDA.

VTA/PBP. In addition, after 6-OHDA injection, in each DA midbrain region, the proportion of $\mathrm{TH}$ cells showing GDNF immunoreactivity was significantly higher than in the control group (Table 1; Fig. 4I and $\mathrm{J}$ ), although no differences were found between rats receiving $300 \mu \mathrm{g}$ and $500 \mu \mathrm{g}$ of $6-$ OHDA.

\section{Discussion}

Our findings confirm previous studies reporting a complementary distribution in the expression pattern of GDNF and its receptor components, with GDNF expression in the striatum and GFR $\alpha 1$ and Ret expression in mesostriatal DA cells (Trupp et al., 1996; Golden et al., 1998; Walker et al., 1998; Sarabi et al., 2001). On the other hand, our findings also show that: (i) the levels of GDNFmRNA are significantly higher in the ventral striatum than in the dorsal striatum; (ii) although all midbrain DA cells express both components of the GDNF receptor, only those lying in A10 and SNrm retrogradely transport GDNF constitutively synthesized in striatum and (iii) this population of midbrain DA cells is more resistant to 6-OHDA than that localized in $\mathrm{SNcv}$, which projects to the dorsal striatum and does not transport GDNF.

In PD, not all midbrain DA cells display the same degree of susceptibility to degeneration. Degeneration starts at caudo-ventrolateral regions of SN and advances towards rostro-dorso-medial regions of SN and A10, where many neurons remain intact until the final stages of the disease (Fearnley \& Lees, 1991; Gibb \& Lees, 1991; Damier et al., 1999). In our experimental model, the topographic pattern of degeneration is similar to that of PD; neurons in the caudo-ventro-lateral region of $\mathrm{SN}$ are more vulnerable than those in the rostro-dorso-medial region of SN and A10, suggesting that i.c.v. injection of 6-OHDA is an appropriate model for studying the differential vulnerability of midbrain DA cells in the pathogenesis of PD. Bearing in mind that the injection site was on the midline, a striking fact is that DA neurons near the midline $(\mathrm{Li} / \mathrm{IF})$, which are exposed to the highest concentration of 

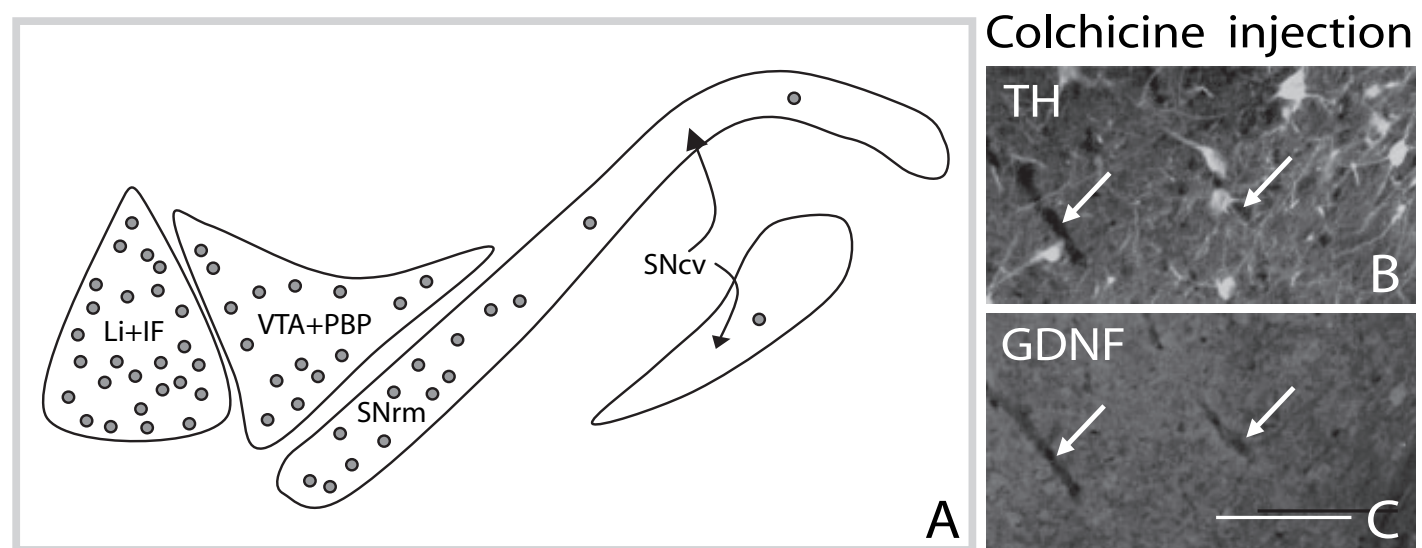

A

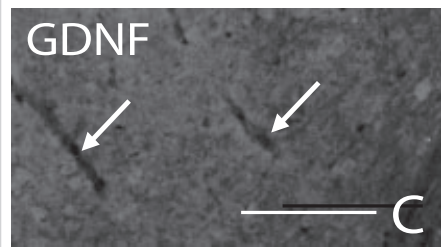

FG injection in Striatum
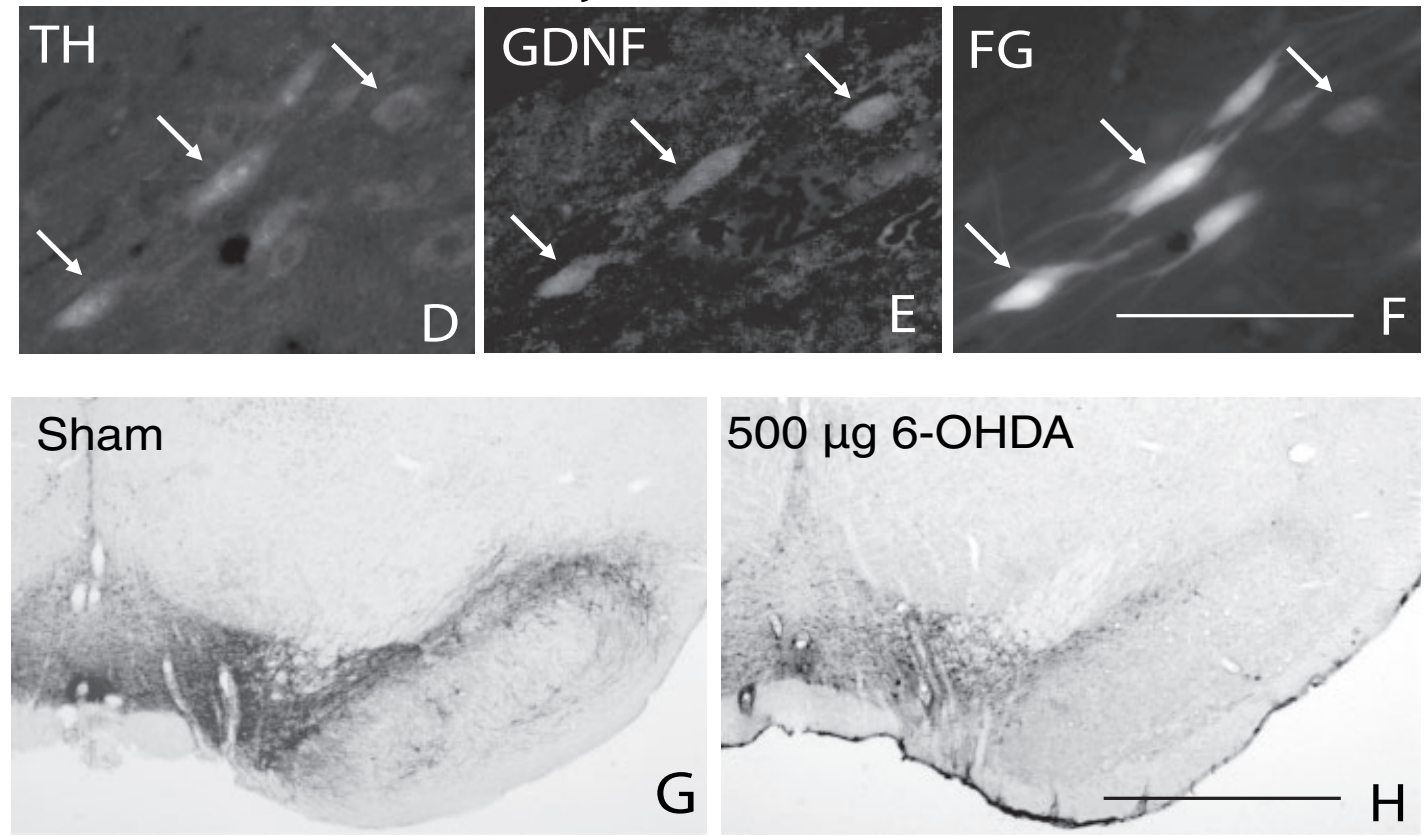

\section{$500 \mu \mathrm{g} 6-\mathrm{OHDA}$}
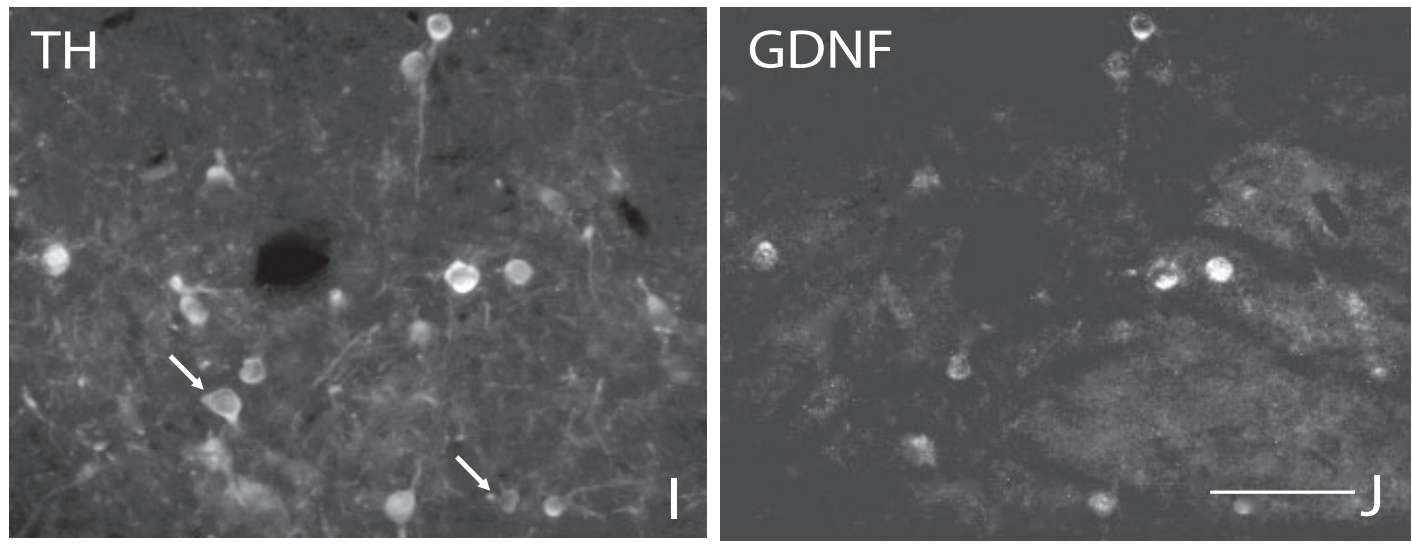

FIG. 4. (A) Schematic drawing illustrating the topographic distribution of TH-GDNF double-labelled cells in A10 (Li+IF and VTA+PBP) and A9 (SNrm and $\mathrm{SNcv}$ ) dopaminergic groups. Neurons were plotted from three frontal sections separated $180 \mu \mathrm{m}$ from each other at the level of the exit of the third nerve. One dot represents four double-labelled cells. (B and C), Double labelling for TH and GDNF in the SNrm after intracerebroventricular injection of colchicine in the lateral ventricle. Note that TH cells are not immunoreactive for GDNF. (D-F) Triple labelling for TH, GDNF and FG in SNrm neurons after FG injection in striatum. (G and $\mathrm{H}$ ), Immunostaining for TH in sham and $500 \mu \mathrm{g}$ 6-OHDA intracerebroventricularly injected rat. (I and J) Double labelling for TH and GDNF in A10 (Li+IF) after intracerebroventricular injection of $500 \mu \mathrm{g}$ of 6-OHDA. Note that the distribution of surviving DA cells $(\mathrm{H})$ matches that of those showing GDNF immunoreactivity (A), and that most surviving TH cells show GDNF immunoreactivity (I and J). Arrows in B and C indicate the same vessels, in D-F they indicate triple labelled cells, and in I, two TH cells immunonegative for GDNF. FG, fluoro-gold; IF, interfascicular nucleus; Li, rostral and caudal linear nuclei; SNcv, caudoventro-lateral region of the substantia nigra; SNrm, rostro-dorso-medial region of the substantia nigra. Scale bar, $50 \mu \mathrm{m}(\mathrm{C}$, for B and C); $40 \mu \mathrm{m}(\mathrm{F}$ and $\mathrm{J}$, for D-F and for I and $\mathrm{J}$, respectively); $1.5 \mathrm{~mm}(\mathrm{H}$, for $\mathrm{G}$ and $\mathrm{H})$. 


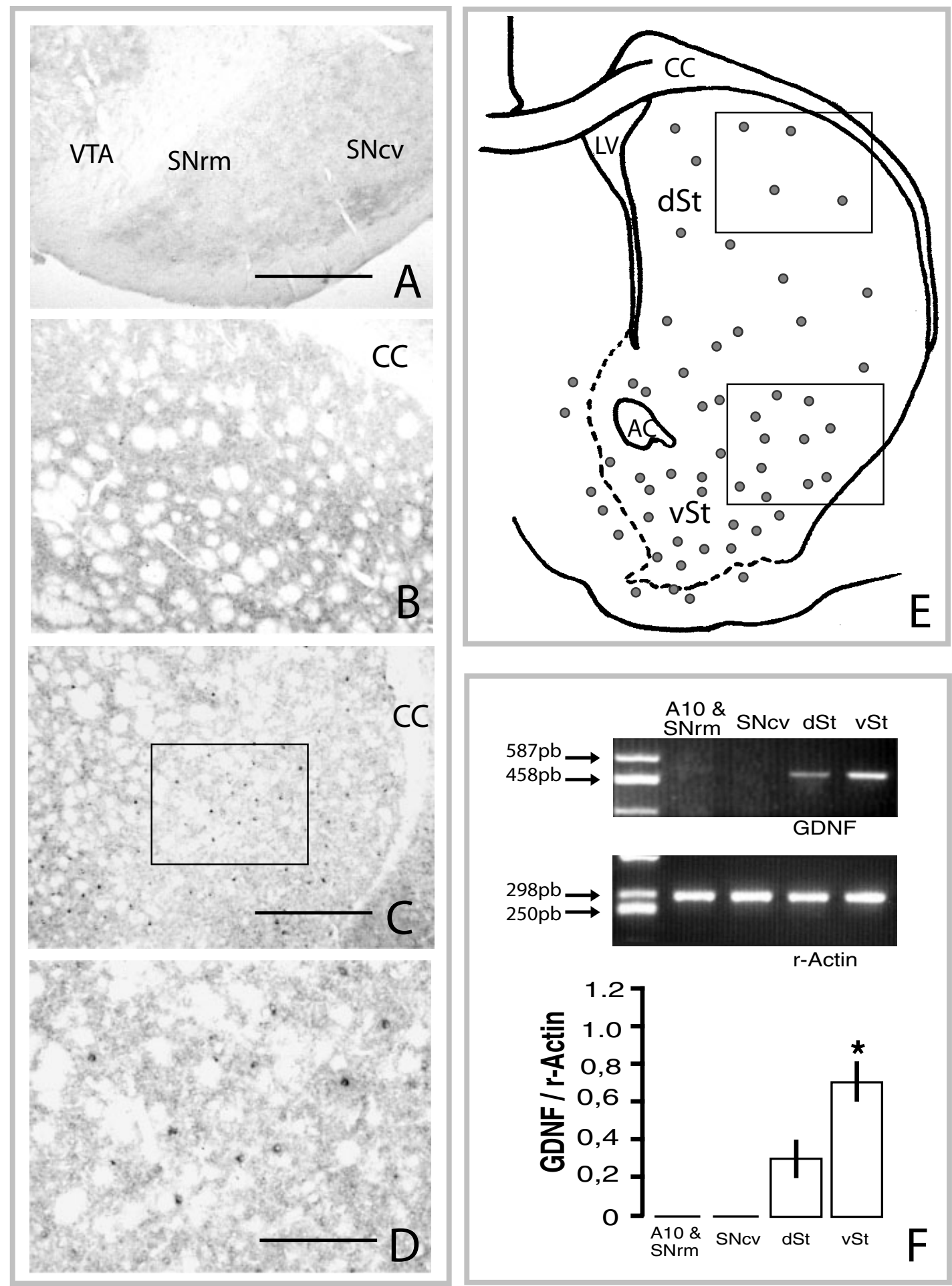

FIG. 5. (A-D) In situ hybridization for GDNF in the midbrain (A) and striatum (B-D). In the midbrain, GDNFmRNA-cells were not detected. In the ventral striatum (C and D) GDNFmRNA-cells were more numerous than in the dorsal striatum (B). (D) Boxed area in C. (E) Schematic drawing showing the topographic distribution of GDNFmRNA-positive cells in the striatum. Stained cells were plotted from two frontal sections separated $180 \mu \mathrm{m}$ from each other at the level of the anterior commissure. One dot represents six labelled cells. Boxed areas approximately correspond to striatal regions in B and C. (F) RT-PCR analysis (top) and densitometric quantification (bottom) of GDNFmRNA expression in the midbrain (A10 \& SNrm and SNcv) and striatum (dSv and vSt). Confirming ISH data (A-D), GDNFcDNA was not amplified in the midbrain, and the levels of GDNFcDNA were significantly higher in the ventral striatum than in the dorsal striatum. A10, A10 dopaminergic cell group; AC, anterior commissure; CC, corpus callosum; dSt, dorsal striatum; SNcv, caduo-ventro-lateral region of the substantia nigra; SNrm; rostro-dorso-medial region of the substantia nigra; vSt, ventral striatum. ${ }^{*} P<0.01$ v.s. dSt. Scale bar, $1 \mathrm{~mm}(\mathrm{~A}) ; 1 \mathrm{~mm}(\mathrm{C}$, for B and C); $300 \mu \mathrm{m}(\mathrm{D})$. 


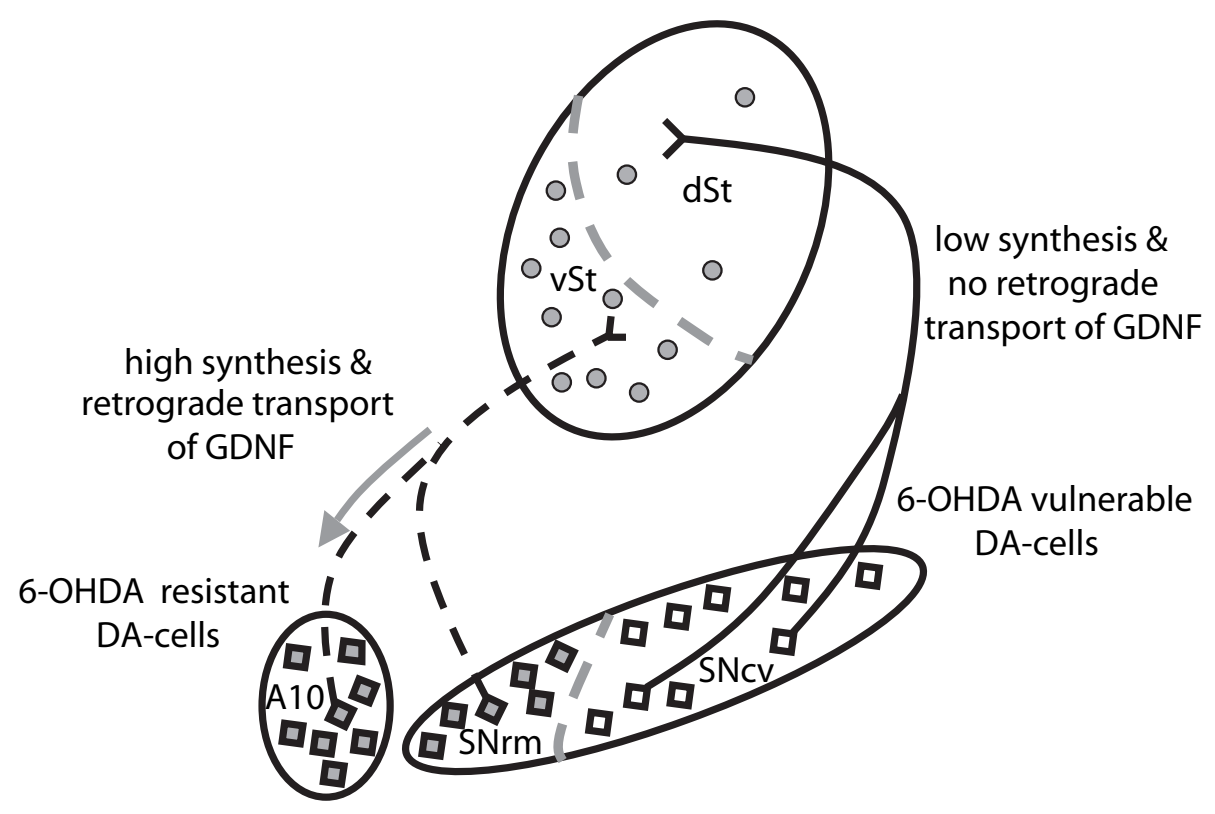

FIG. 6. Schematic representation of the two mesostriatal dopaminergic systems, one originating in the A10 and SNrm, composed of 6-OHDA resistant DA cells that project to the vSt, where GDNF synthesis is high, and another coming from the SNcv, composed of 6-OHDA vulnerable DA cells that project to the dSt, where GDNF synthesis is low. A10, A10 dopaminergic cell group; dSt, dorsal striatum; SNcv, caudo-ventro-lateral region of the substantia nigra; SNrm; rostro-dorsomedial region of the substantia nigra; vSt, ventral striatum.

neurotoxin, paradoxically display the highest resistance to degeneration, while those in SNcv, the most distant ones from the injection place, display the highest vulnerability. The differential vulnerability between different DA cell subpopulations has been attributed to differences in their phenotypic profile. So, neurons expressing the calcium binding protein calbindin have been considered more resistant (Yamada et al., 1990; Lavoie \& Parent, 1991; Gaspar et al., 1994), while those containing high levels of dopamine transporter (Shimada et al., 1992; Cerruti et al., 1993; Hurd et al., 1994; Uhl et al., 1994; GonzalezHernandez et al., 2004), and more recently, those expressing the homeobox factor Pitx3 (Hwang et al., 2003; Smidt et al., 2004) have been considered more vulnerable. However, current data about the neurochemical profile of DA cells do not support that GDNF is involved in the differential vulnerability because they do not express GDNF and show no differences in the expression pattern of the GDNF receptor components (Trupp et al., 1996; Golden et al., 1998; Sarabi et al., 2001; present study). Interestingly, although DA cells do not contain GDNFmRNA, those lying in the SNrm and A10 are immunopositive for GDNF. As these neurons project to the ventral striatum, the striatal region containing the highest levels of GDNFmRNA, GDNF in DA somata probably comes from their target cells in the striatum. This hypothesis is supported by the fact that immunoreactivity for GDNF in A10 and SNrm DA cells disappears after i.c.v. injection of colchicine, and by previous studies reporting GDNF retrograde transport after being injected (Tomac et al., 1995b; Lapchak et al., 1997; Kordower et al., 2000) or experimentally induced (Naveilhan et al., 1997). The close parallel between the distribution pattern of DA cells showing immunopositivity for GDNF and those surviving after i.c.v. injection of 6-OHDA suggests that GDNF exerts a neuroprotective role on DA cells, although in this case, neuroprotection does not depend on the neurochemical profile of DA cells but on the topography of their projections and the synthesis of GDNF by their target cells. Therefore, we can distinguish two different populations of mesostriatal DA cells (Fig. 6), one localized in the SNcv, which projects to the dorsal striatum, does not transport GDNF and is vulnerable to i.c.v. injection of 6-OHDA, and the other localized in the SNrm and A10, which projects to the ventral striatum, transports GDNF and is resistant to i.c.v. injection of 6-OHDA. Interestingly, a previous study has also reported differences in the actions of GDNF on A9 and A10 cells (Kholodilov et al., 2004). In GDNF overexpressing mice, the number of A9 DA cells surviving after the natural cell death occurring during the first postnatal days is higher than in their wild-type strain, but this effect is transient because the number of SN DA cells is similar in both strains in adulthood. In contrast, with respect to A10 cells, this effect is persistent as the increase in the number of DA cells continues into adulthood. These data are consistent with our idea that the neuroprotective effect of GDNF is stronger on dorsomedial than on ventromedial midbrain DA cells, although factors involved in this phenomenon could include others apart from topographical differences in its striatal synthesis. On the other hand, it should be noted that although the count of double-labelled cells revealed a close relationship between GDNF immunoreactivity and resistance to 6-OHDA, we found no differences between rats receiving $300 \mu \mathrm{g}$ and $500 \mu \mathrm{g}$ of $6-$ OHDA (see Table 1), suggesting that other factors could also be involved in the differential resistance of midbrain DA cells to 6-OHDA or that high doses of 6-OHDA can inhibit the retrograde transport of GDNF.

Until recently, a large body of evidence suggested that the neuroprotective effect of GDNF came from its ability to induce enhancement of dopaminergic hallmarks in intact and lesioned DA cells. Studies using acute or chronic administration of GDNF have reported an increase in neuronal excitability, spontaneous firing rate, release and turnover of DA, TH immunostaining, number and size of TH cells in the $\mathrm{SN}$ and number of TH fibres in the striatum (Gash et al., 1995; Bilang-Bleuel et al., 1997; Grondin \& Gash, 1998; Bjorklund et al., 2000; Kordower et al., 2000; Kirik et al., 2001; Grondin et al., 2002; Maswood et al., 2002; Palfi et al., 2002; Grondin et al., 2003). However, the expression of a strong dopaminergic phenotype and maintenance of high metabolic activity contrasts with our idea of neuroprotection because dopamine metabolism is an important source of reactive oxygen species, which play a damaging rather than a protective role. Therefore, in spite of the fact that these effects were observed after exogenous administration of GDNF, and they probably play a relevant role during the development of 
DA cells, it is improbable that under physiological conditions they are responsible for a long-term neuroprotective effect in adulthood. Interestingly, other studies report that sustained infusion (Lu \& Hagg, 1997) or lentiviral vector delivery (Rosenblad et al., 2003; Georgievska et al., 2004) of GDNF produce a reduction in the levels of mRNA and protein $\mathrm{TH}$ as well as its enzymatic activity, suggesting that GDNF induces $\mathrm{TH}$ down-regulation by acting directly on its gene expression. On the other hand, it is known that the signalling pathway of GDNF is regulated by protein and lipid kinases and phospholipases (Saarma, 2000, 2001; Paratcha et al., 2001; Sariola \& Saarma, 2003), by means of which it induces TH phosphorylation (Salvatore et al., 2004). So, GDNF can exert its neuroprotective effect acting at transcriptional and transductional levels in the synthesis of different molecules that determine phenotypic differences in DA cells. In this respect, it is interesting to note that the levels of THmRNA and DAT mRNA and protein (Blanchard et al., 1994; Hurd et al., 1994; Haber et al., 1995; Gonzalez-Hernandez et al., 2004) are lower in DA cells lying in A10 and SNrm than in those lying in the SNcv, although the possibility that these phenotypic differences might be due to differences in GDNF expression in their target cells remains to be explored.

In spite of the fact that the retrograde transport of GDNF was described for the first time ten years ago (Tomac et al., 1995b) and thereafter supported by several studies (Lapchak et al., 1997; Naveilhan et al., 1997; Kordower et al., 2000), with respect to the molecular mechanisms underlying this phenomenon, we only know that it may be internalized together with GFR $\alpha 1$, independently of Ret tyrosine kinase activity (Vieira et al., 2003), and its functional meaning remains unknown. In contrast to the neurotrophins (nerve growth factor, brain derived neurotrophic factor and neurotrophin 3 and 4), whose presence in the soma of afferent neurons is substantiated by the fact that their biological actions require binding to tyrosine kinase receptors in axon terminals and the subsequent internalization and retrograde transport of the complex to the cell body (Grimes et al., 1996; Howe et al., 2001; Ginty \& Segal, 2002), in the case of GDNF, although we know a lot about its complex signalling biology (Saarma, 2000, 2001 Paratcha et al., 2001; Sarabi et al., 2001), no pathways currently proposed include internalization and transport of the ligand. Our results show that GDNF is internalized and retrogradely transported, not only after being injected or when its overexpression is experimentally induced, but also under physiological conditions. Further studies should be addressed to elucidating the molecular mechanisms responsible for its internalization and transport, and more importantly, whether this is a new signalling pathway involved in neuroprotection or only a route for its degradation.

\section{Acknowledgements}

Partially supported by the Gobierno Autónomo de Canarias (PI 042004/047) and Ministerio de Educación y Ciencia de España (grant number BFU200405756). PBC is supported by a grant from Fundación Canaria de Investigación y Salud (FUNCIS), and ICM is supported by a grant from red de Centros de Investigación de Enfermedades Neurológicas (CIEN).

\section{Abbreviations}

DA, dopaminergic; dSt, dorsal striatum; FG, fluoro-gold; GDNF, glial cell linederived neurotrophic factor; GFR $\alpha 1, \alpha$ subunit of GDNF receptor; IF, interfascicular nucleus; ISH, in situ hybridization; Li, rostral and caudal linear nuclei; PBP, parabrachial pigmented nucleus; PD, Parkinson's disease; Ret, tyrosine kinase signalling subunit of GDNF receptor; SN, substantia nigra; SNC, substantia nigra, pars compacta; SNcv, caudo-ventro-lateral region of SN; SNR, substantia nigra, pars reticulata; SNrm, rostro-dorso-medial region of the $\mathrm{SN}$; TH, tyrosine hydroxylase; vSt, ventral striatum; VTA, ventral tegmental area; 6-OHDA, 6- hydroxydopamine.

\section{References}

Airaksinen, M.S., Titievsky, A. \& Saarma, M. (1999) GDNF family neurotrophic factor signaling: four masters, one servant? Mol. Cell Neurosci., 13, 313-325.

Arenas, E., Trupp, M., Akerud, P. \& Ibanez, C.F. (1995) GDNF prevents degeneration and promotes the phenotype of brain noradrenergic neurons in vivo. Neuron, 15, 1465-1473.

Baloh, R.H., Enomoto, H., Johnson, E.M. Jr \& Milbrandt, J. (2000) The GDNF family ligands and receptors - implications for neural development. Curr. Opin. Neurobiol., 10, 103-110.

Bernheimer, H., Birkmayer, W., Hornykiewicz, O., Jellinger, K. \& Seitelberger, F. (1973) Brain dopamine and the syndromes of Parkinson and Huntington. Clinical, morphological and neurochemical correlations. J. Neurol. Sci., 20, 415-455.

Bilang-Bleuel, A., Revah, F., Colin, P., Locquet, I., Robert, J.J., Mallet, J. \& Horellou, P. (1997) Intrastriatal injection of an adenoviral vector expressing glial-cell-line-derived neurotrophic factor prevents dopaminergic neuron degeneration and behavioral impairment in a rat model of Parkinson disease. Proc. Natl Acad. Sci. USA, 94, 8818-8823.

Bjorklund, A., Kirik, D., Rosenblad, C., Georgievska, B., Lundberg, C. \& Mandel, R.J. (2000) Towards a neuroprotective gene therapy for Parkinson's disease: use of adenovirus, AAV and lentivirus vectors for gene transfer of GDNF to the nigrostriatal system in the rat Parkinson model. Brain Res., 886, 82-98.

Blanchard, V., Raisman-Vozari, R., Vyas, S., Michel, P.P., Javoy-Agid, F., Uhl, G. \& Agid, Y. (1994) Differential expression of tyrosine hydroxylase and membrane dopamine transporter genes in subpopulations of dopaminergic neurons of the rat mesencephalon. Brain Res. Mol. Brain Res., 22, 29-38.

Blum, M. \& Weickert, C.S. (1995) GDNF mRNA expression in normal postnatal development, aging, and in Weaver mutant mice. Neurobiol. Aging, 16, 925-929.

Bourque, M.J. \& Trudeau, L.E. (2000) GDNF enhances the synaptic efficacy of dopaminergic neurons in culture. Eur. J. Neurosci., 12, 3172-3180.

Cerruti, C., Walther, D.M., Kuhar, M.J. \& Uhl, G.R. (1993) Dopamine transporter mRNA expression is intense in rat midbrain neurons and modest outside midbrain. Brain Res. Mol. Brain Res., 18, 181-186.

Chiueh, C.C., Burns, R.S., Markey, S.P., Jacobowitz, D.M. \& Kopin, I.J. (1985) Primate model of parkinsonism: selective lesion of nigrostriatal neurons by 1-methyl-4-phenyl-1,2,3,6-tetrahydropyridine produces an extrapyramidal syndrome in rhesus monkeys. Life Sci., 36, 213-218.

Choi-Lundberg, D.L. \& Bohn, M.C. (1995) Ontogeny and distribution of glial cell line-derived neurotrophic factor (GDNF) mRNA in rat. Brain Res. Dev. Brain Res., 85, 80-88.

Dahlström, A. \& Fuxe, K. (1964) Evidence for the existence of monoaminecontaining neurons in the central nervous system - I. Demonstration of monoamines in the cell bodies of brain stem neurons. Acta Physiol. Scand., 62, $1-55$.

Damier, P., Hirsch, E.C., Agid, Y. \& Graybiel, A.M. (1999) The substantia nigra of the human brain. II. Patterns of loss of dopamine-containing neurons in Parkinson's disease. Brain, 122, 1437-1448.

Dressler, G. (2002) Tubulogenesis in the developing mammalian kidney. Trends Cell Biol., 12, 390-395.

Fallon, J.H. \& Moore, R.Y. (1978) Catecholamine innervation of the basal forebrain. IV. Topography of the dopamine projection to the basal forebrain and neostriatum. J. Comp. Neurol., 180, 545-580.

Fearnley, J.M. \& Lees, A.J. (1991) Ageing and Parkinson's disease: substantia nigra regional selectivity. Brain, 114, 2283-2301.

Gash, D.M., Zhang, Z., Cass, W.A., Ovadia, A., Simmerman, L., Martin, D., Russell, D., Collins, F., Hoffer, B.J. \& Gerhardt, G.A. (1995) Morphological and functional effects of intranigrally administered GDNF in normal rhesus monkeys. J. Comp. Neurol., 363, 345-358.

Gaspar, P., Ben Jelloun, N. \& Febvret, A. (1994) Sparing of the dopaminergic neurons containing calbindin-D28k and of the dopaminergic mesocortical projections in weaver mutant mice. Neuroscience, 61, 293-305.

Georgievska, B., Kirik, D. \& Bjorklund, A. (2004) Overexpression of glial cell line-derived neurotrophic factor using a lentiviral vector induces time- and dose-dependent downregulation of tyrosine hydroxylase in the intact nigrostriatal dopamine system. J. Neurosci., 24, 6437-6445.

Gerfen, C.R., Herkenham, M. \& Thibault, J. (1987) The neostriatal mosaic. II. Patch- and matrix-directed mesostriatal dopaminergic and non-dopaminergic systems. J. Neurosci., 7, 3915-3934.

Gibb, W.R. \& Lees, A.J. (1991) Anatomy, pigmentation, ventral and dorsal subpopulations of the substantia nigra, and differential cell death in Parkinson's disease. J. Neurol. Neurosurg. Psychiatry, 54, 388-396. 
Gill, S.S., Patel, N.K., Hotton, G.R., O’Sullivan, K., McCarter, R., Bunnage, M., Brooks, D.J., Svendsen, C.N. \& Heywood, P. (2003) Direct brain infusion of glial cell line-derived neurotrophic factor in Parkinson disease. Nature Med., 9, 589-595.

Ginty, D.D. \& Segal, R.A. (2002) Retrograde neurotrophin signaling: Trk-ing along the axon. Curr. Opin. Neurobiol., 12, 268-274.

Golden, J.P., Baloh, R.H., Kotzbauer, P.T., Lampe, P.A., Osborne, P.A., Milbrandt, J. \& Johnson, E.M. Jr (1998) Expression of neurturin, GDNF, and their receptors in the adult mouse CNS. J. Comp. Neurol., 398, 139-150.

Gonzalez-Hernandez, T., Barroso-Chinea, P., De La CruZ. Muros, I., Del Mar. Perez-Delgado, M. \& Rodriguez, M. (2004) Expression of dopamine and vesicular monoamine transporters and differential vulnerability of mesostriatal dopaminergic neurons. J. Comp. Neurol., 479, 198-215.

Gonzalez-Hernandez, T. \& Rodriguez, M. (2000) Compartmental organization and chemical profile of dopaminergic and GABAergic neurons in the substantia nigra of the rat. J. Comp. Neurol., 421, 107-135.

Grimes, M.L., Zhou, J., Beattie, E.C., Yuen, E.C., Hall, D.E., Valletta, J.S., Topp, K.S., LaVail, J.H., Bunnett, N.W. \& Mobley, W.C. (1996) Endocytosis of activated TrkA: evidence that nerve growth factor induces formation of signaling endosomes. J. Neurosci., 16, 7950-7964.

Grondin, R., Cass, W.A., Zhang, Z., Stanford, J.A., Gash, D.M. \& Gerhardt, G.A. (2003) Glial cell line-derived neurotrophic factor increases stimulusevoked dopamine release and motor speed in aged rhesus monkeys. J. Neurosci., 23, 1974-1980.

Grondin, R. \& Gash, D.M. (1998) Glial cell line-derived neurotrophic factor (GDNF): a drug candidate for the treatment of Parkinson's disease. J. Neurol., 245, 35-42.

Grondin, R., Zhang, Z., Yi, A., Cass, W.A., Maswood, N., Andersen, A.H., Elsberry, D.D., Klein, M.C., Gerhardt, G.A. \& Gash, D.M. (2002) Chronic, controlled GDNF infusion promotes structural and functional recovery in advanced parkinsonian monkeys. Brain, 125, 2191-2201.

Haber, S.N., Ryoo, H., Cox, C. \& Lu, W. (1995) Subsets of midbrain dopaminergic neurons in monkeys are distinguished by different levels of mRNA for the dopamine transporter: comparison with the mRNA for the D2 receptor, tyrosine hydroxylase and calbindin immunoreactivity. J. Comp. Neurol., 362, 400-410.

Henderson, C.E., Phillips, H.S., Pollock, R.A., Davies, A.M., Lemeulle, C., Armanini, M., Simmons, L., Moffet, B., Vandlen, R.A. \& Simpson, L.C. (1994) GDNF: a potent survival factor for motoneurons present in peripheral nerve and muscle. Science, 266, 1062-1064.

Herrero, M.T., Perez-Otano, I., Oset, C., Kastner, A., Hirsch, E.C., Agid, Y., Luquin, M.R., Obeso, J.A. \& Del Rio, J. (1993) GM-1 ganglioside promotes the recovery of surviving midbrain dopaminergic neurons in MPTP-treated monkeys. Neuroscience, 56, 965-972.

Hirsch, E., Graybiel, A.M. \& Agid, Y.A. (1988) Melanized dopaminergic neurons are differentially susceptible to degeneration in Parkinson's disease. Nature, 334, 345-348.

Howe, C.L., Valletta, J.S., Rusnak, A.S. \& Mobley, W.C. (2001) NGF signaling from clathrin-coated vesicles: evidence that signaling endosomes serve as a platform for the Ras-MAPK pathway. Neuron, 32, 801-814.

Hurd, Y.L., Pristupa, Z.B., Herman, M.M., Niznik, H.B. \& Kleinman, J.E. (1994) The dopamine transporter and dopamine D2 receptor messenger RNAs are differentially expressed in limbic- and motor-related subpopulations of human mesencephalic neurons. Neuroscience, 63, 357-362.

Hwang, D.Y., Ardayfio, P., Kang, U.J., Semina, E.V. \& Kim, K.S. (2003) Selective loss of dopaminergic neurons in the substantia nigra of Pitx3deficient aphakia mice. Brain Res. Mol. Brain Res., 114, 123-131.

Jimenez-Castellanos, J. \& Graybiel, A.M. (1987) Subdivisions of the dopamine-containing A8-A9-A10 complex identified by their differential mesostriatal innervation of striosomes and extrastriosomal matrix. Neuroscience, 23, 223-242.

Jing, S., Wen, D., YuY., Holst, P.L., Luo, Y., Fang, M., Tamir, R., Antonio, L., Hu, Z., Cupples, R., Louis, J.C., Hu, S., Altrock, B.W. \& Fox, G.M. (1996) GDNF-induced activation of the ret protein tyrosine kinase is mediated by GDNFR-alpha, a novel receptor for GDNF. Cell, 85, 1113-1124.

Joel, D. \& Weiner, I. (2000) The connections of the dopaminergic system with the striatum in rats and primates: an analysis with respect to the functional and compartmental organization of the striatum. Neuroscience, 96, 451-474.

Kholodilov, N., Yarygina, O., Oo, T.F., Zhang, H., Sulzer, D., Dauer, W. \& Burke, R.E. (2004) Regulation of the development of mesencephalic dopaminergic systems by the selective expression of glial cell line-derived neurotrophic factor in their targets. J. Neurosci., 24, 3136-3146.

Kirik, D., Georgievska, B., Rosenblad, C. \& Bjorklund, A. (2001) Delayed infusion of GDNF promotes recovery of motor function in the partial lesion model of Parkinson's disease. Eur. J. Neurosci., 13, 1589-1599.
Kordower, J.H., Emborg, M.E., Bloch, J., Ma, S.Y., Chu, Y., Leventhal, L., McBride, J., Chen, E.Y., Palfi, S., Roitberg, B.Z., Brown, W.D., Holden, J.E., Pyzalski, R., Taylor, M.D., Carvey, P., Ling, Z., Trono, D., Hantraye, P., Deglon, N. \& Aebischer, P. (2000) Neurodegeneration prevented by lentiviral vector delivery of GDNF in primate models of Parkinson's disease. Science, 290, 767-773.

Kordower, J.H., Palfi, S., Chen, E.Y., Ma, S.Y., Sendera, T., Cochran, E.J., Mufson, E.J., Penn, R., Goetz, C.G. \& Comella, C.D. (1999) Clinicopathological findings following intraventricular glial-derived neurotrophic factor treatment in a patient with Parkinson's disease. Ann. Neurol., 46, 419-424.

Krieglstein, K. (2004) Factors promoting survival of mesencephalic dopaminergic neurons. Cell Tissue Res., 318, 73-80.

Lapchak, P.A., Jiao, S., Collins, F. \& Miller, P.J. (1997) Glial cell line-derived neurotrophic factor: distribution and pharmacology in the rat following a bolus intraventricular injection. Brain Res., 747, 92-102.

Lavoie, B. \& Parent, A. (1991) Dopaminergic neurons expressing calbindin in normal and parkinsonian monkeys. Neuroreport, 2, 601-604.

Lin, L.F., Doherty, D.H., Lile, J.D., Bektesh, S. \& Collins, F. (1993) GDNF: a glial cell line-derived neurotrophic factor for midbrain dopaminergic neurons. Science, 260, 1130-1132.

Longo, V.G. (1973) Central effects of 6-hydroxydopamine. Behav. Biol., 9, $397-420$.

Lu, X. \& Hagg, T. (1997) Glial cell line-derived neurotrophic factor prevents death, but not reductions in tyrosine hydroxylase, of injured nigrostriatal neurons in adult rats. J. Comp. Neurol., 388, 484- 494.

Ma, D., Wang, X. \& Hang, J. (2000) NIH 3T3 cells or engineered NIH 3T3 cells stably expressing GDNF can protect primary dopaminergic neurons. Neurol. Res., 22, 538-544.

Maswood, N., Grondin, R., Zhang, Z., Stanford, J.A., Surgener, S.P., Gash, D.M. \& Gerhardt, G.A. (2002) Effects of chronic intraputamenal infusion of glial cell line-derived neurotrophic factor (GDNF) in aged Rhesus monkeys. Neurobiol. Aging, 23, 881-889.

McRitchie, D.A., Hardman, C.D. \& Halliday, G.M. (1996) Cytoarchitectural distribution of calcium binding proteins in midbrain dopaminergic regions of rats and humans. J. Comp. Neurol., 364, 121-150.

Naveilhan, P.E.I., Shamy, W.M. \& Ernfors, P. (1997) Differential regulation of mRNAs for GDNF and its receptors Ret and GDNFR alpha after sciatic nerve lesion in the mouse. Eur. J. Neurosci., 9, 1450-1460.

Nutt, J.G., Burchiel, K.J., Comella, C.L., Jankovic, J., Lang, A.E., Laws, E.R. Jr, Lozano, A.M., Penn, R.D., Simpson, R.K. Jr, Stacy, M. \& Wooten, G.F. (2003) Randomized, double-blind trial of glial cell line-derived neurotrophic factor (GDNF) in PD. Neurology, 60, 69-73.

Palfi, S., Leventhal, L., Chu, Y., Ma, S.Y., Emborg, M., Bakay, R., Deglon, N., Hantraye, P., Aebischer, P. \& Kordower, J.H. (2002) Lentivirally delivered glial cell line-derived neurotrophic factor increases the number of striatal dopaminergic neurons in primate models of nigrostriatal degeneration. J. Neurosci., 22, 4942-4954.

Paratcha, G., Ledda, F., Baars, L., Coulpier, M., Besset, V., Anders, J., Scott, R. \& Ibanez, C.F. (2001) Released GFRalphal potentiates downstream signaling, neuronal survival, and differentiation via a novel mechanism of recruitment of c-Ret to lipid rafts. Neuron, 29, 171-184.

Paxinos, G. \& Watson, C. (1998) The Rat Brain in Stereotaxic Coordinates. Academic Press, Orlando, Florida.

Rodriguez, M., Abdala, P., Barroso-Chinea, P., Obeso, J. \& GonzalezHernandez, T. (2001a) Motor behavioural changes after intracerebroventricular injection of 6-hydroxydopamine in the rat: an animal model of Parkinson's disease. Behav. Brain Res., 122, 79-92.

Rodriguez, M., Barroso-Chinea, P., Abdala, P., Obeso, J. \& GonzalezHernandez, T. (2001b) Dopamine cell degeneration induced by intraventricular administration of 6-hydroxydopamine in the rat: similarities with cell loss in parkinson's disease. Exp. Neurol., 169, 163-181.

Rosenblad, C., Georgievska, B. \& Kirik, D. (2003) Long-term striatal overexpression of GDNF selectively downregulates tyrosine hydroxylase in the intact nigrostriatal dopamine system. Eur. J. Neurosci., 17, $260-270$

Saarma, M. (2000) GDNF - a stranger in the TGF-beta superfamily? Eur. J. Biochem., 267, 6968-6971.

Saarma, M. (2001) GDNF recruits the signaling crew into lipid rafts. TINS, 24, $427-429$

Salvatore, M.F., Zhang, J.L., Large, D.M., Wilson, P.E., Gash, C.R., Thomas, T.C., Haycock, J.W., Bing, G., Stanford, J.A., Gash, D.M. \& Gerhardt, G.A. (2004) Striatal GDNF administration increases tyrosine hydroxylase phosphorylation in the rat striatum and substantia nigra. J. Neurochem., 90, 245-254. 
Sarabi, A., Hoffer, B.J., Olson, L. \& Morales, M. (2001) GFRalpha-1 mRNA in dopaminergic and nondopaminergic neurons in the substantia nigra and ventral tegmental area. J. Comp. Neurol., 441, 106-117.

Sariola, H. \& Saarma, M. (2003) Novel functions and signalling pathways for GDNF. J. Cell Sci., 116, 3855-3862.

Schneider, J.S., Yuwiler, A. \& Markham, C.H. (1987) Selective loss of subpopulations of ventral mesencephalic dopaminergic neurons in the monkey following exposure to MPTP. Brain Res., 411, 144-150.

Shimada, S., Kitayama, S., Walther, D. \& Uhl, G. (1992) Dopamine transporter mRNA: dense expression in ventral midbrain neurons. Brain Res. Mol. Brain Res., 13, 359-362.

Smidt, M.P., Smits, S.M. \& Burbach, J.P. (2004) Homeobox gene Pitx3 and its role in the development of dopamine neurons of the substantia nigra. Cell Tissue Res., 318, 35-43.

Springer, J.E., Mu, X., Bergmann, L.W. \& Trojanowski, J.Q. (1994) Expression of GDNF mRNA in rat and human nervous tissue. Exp. Neurol., 127, 167170.

Stromberg, I., Bjorklund, L., Johansson, M., Tomac, A., Collins, F., Olson, L., Hoffer, B. \& Humpel, C. (1993) Glial cell line-derived neurotrophic factor is expressed in the developing but not adult striatum and stimulates developing dopamine neurons in vivo. Exp. Neurol., 124, 401-412.

Tomac, A., Lindqvist, E., Lin, L.F., Ogren, S.O., Young, D., Hoffer, B.J. \& Olson, L. (1995a) Protection and repair of the nigrostriatal dopaminergic system by GDNF in vivo. Nature, 373, 335-339.

Tomac, A., Widenfalk, J., Lin, L.F., Kohno, T., Ebendal, T., Hoffer, B.J. \& Olson, L. (1995b) Retrograde axonal transport of glial cell line-derived neurotrophic factor in the adult nigrostriatal system suggests a trophic role in the adult. Proc. Natl Acad. Sci. USA, 92, 8274-8278.

Trupp, M., Arenas, E., Fainzilber, M., Nilsson, A.S., Sieber, B.A., Grigoriou, M., Kilkenny, C., Salazar-Grueso, E., Pachnis, V. \& Arumae, U. (1996) Functional receptor for GDNF encoded by the c-ret proto-oncogene. Nature, 381, 785789.

Uhl, G.R., Walther, D., Mash, D., Faucheux, B. \& Javoy-Agid, F. (1994) Dopamine transporter messenger RNA in Parkinson's disease and control substantia nigra neurons. Ann. Neurol., 35, 494-498.

Ungerstedt, U. (1971) Striatal dopamine release after amphetamine or nerve degeneration revealed a rotational behavior. Acta Physiol. Scan. Supplement, 367, 49-68.

Varastet, M., Riche, D., Maziere, M. \& Hantraye, P. (1994) Chronic MPTP treatment reproduces in baboons the differential vulnerability of mesencephalic dopaminergic neurons observed in Parkinson's disease. Neuroscience, 63, 47-56.

Vieira, P., Thomas-Crusells, J. \& Vieira, A. (2003) Internalization of glial cellderived neurotrophic factor receptor GFR alpha 1 in the absence of the ret tyrosine kinase coreceptor. Cell Mol. Neurobiol., 23, 43-55.

Viglietto, G., Dolci, S., Bruni, P., Baldassarre, G., Chiariotti, L., Melillo, R.M., Salvatore, G., Chiappetta, G., Sferratore, F., Fusco, A. \& Santoro, M. (2000) Glial cell line-derived neutrotrophic factor and neurturin can act as paracrine growth factors stimulating DNA synthesis of Ret-expressing spermatogonia. Int. J. Oncol., 16, 689-694.

Walker, D.G., Beach, T.G., Xu, R., Lile, J., Beck, K.D., McGeer, E.G. \& McGeer, P.L. (1998) Expression of the proto-oncogene Ret, a component of the GDNF receptor complex, persists in human substantia nigra neurons in Parkinson's disease. Brain Res., 792, 207-217.

Yamada, T., McGeer, P.L., Baimbridge, K.G. \& McGeer, E.G. (1990) Relative sparing in Parkinson's disease of substantia nigra dopamine neurons containing calbindin-D28K. Brain Res., 526, 303-307.

Zigmond, M.J. \& Stricker, E.M. (1973) Recovery of feeding and drinking by rats after intraventricular 6-hydroxydopamine or lateral hypothalamic lesions. Science, 182, 717-720. 